\title{
Globalization and its Impacts on Communication in Self-Government
}

\author{
Lenka Labudová, ${ }^{1,}$, and Denisa Jánošová ${ }^{2}$ \\ ${ }^{1}$ University of Ss. Cyril and Methodius in Trnava, Faculty of Mass Media Communication, \\ Department of Marketing Communication, Nám. J. Herdu 2, 917 01, Trnava, Slovakia \\ ${ }^{2}$ University of Ss. Cyril and Methodius in Trnava, Faculty of Mass Media Communication, \\ Department of Marketing Communication, Nám. J. Herdu 2, 917 01, Trnava, Slovakia
}

\begin{abstract}
.
Research background: Globalization has significantly affected the way a territory communicates its offer. Only public administration, which is innovative and at the same time effective in its activities, can adapt and respond to the ever-changing conditions and requirements of today's society and its members. Innovation and its activities, research and development are the result of proliferation and they are considered to be the driving force behind the growth of the economy, in the form of new knowledge. Those regions that have spent more money and effort on innovation activities in the past are now at a more advanced level. These are the main reasons to focus on this topic and bring the results of our research.

Purpose of the article: The aim of the article is to present the findings which show the level of communication between the municipality and the public and the possibilities of using communication tools towards their more effective usage.

Methods: It presents the results of a questionnaire survey realized at the level of local governments in the Trnava region. The results of the questionnaire survey with a description and explanation are shown graphically. The offices we asked were the following: Trnava City Office, Trnava Self-Governing Region Office, Trnava District Office.

Findings and value added: The article presents the findings of a survey that was carried out for the purpose of the dissertation which deals with regional marketing communications. The outcome of the survey specified the direction of the main research in our dissertation.
\end{abstract}

Keywords: region; marketing; communication; innovation; globalization

JEL Classification: $R 58 ; R 50 ; M 31$

${ }^{*}$ Corresponding author: 2764922@,student.ucm.sk 


\section{Introduction}

Globalization is a phenomenon without borders. It connects cultures and transforms society. It also brings about changes that have affected the world economy, world trade, transport, the environment and other important areas such as the development and progress of countries and regions. It is also often referred to as a driving force for change, which has accelerated various areas of life such as information and communication technologies, new forms of competitiveness, digitization or innovation.

Innovations in self-governments represent changes that lead to the creation of special processes. The intention is to improve the current and future state in terms of professional, qualification or organizational aspects.

The effectiveness of the development of an innovative self-government can help to reduce disparities between individual self-governments.

\section{Theoretical background}

\subsection{Globalization}

The definition of globalization can be approached from different perspectives. A clear definition of the term is quite problematic. An interesting look at the definition of this term is provided by U. Beck, who points out that "globalization is certainly the most frequently used, misused and the rarest defined term of recent but also incoming terms. " [1]

The new economy creates conditions for a new conception of thinking, based on new knowledge, with the use of information and communication technologies. In accordance with the principles of globalization.[2]

Krejčí draws his attention to the idea of globalization as a "process of global information, technological and economic interconnection. In a broader sense, globalization also involves the transformation of the political system, the formation of a global mass culture and global problems." [3] Globalization is about the transmission of persons, processes and products from one part of the world to another. This is a process through which material and social phenomena generated in one part of the world become part of the lives of people in other parts of the globe [4]. Jens Bartelson [5] analyses in more detail the concept of globalization since it has undergone significant changes over the last ten years. He considers globalization to be a process of interaction and transfer between existing units, exchange across existing unit boundaries as well as between units and a system, but with an assumption that this system and units remain the same throughout the whole globalization process.

The times we live in can be called the times of change. The impulses for these changes can be found in the development of advanced technologies. Those have the ability to connect information, the economy and society as a whole. Globalization is characterized by ever - accelerating scientific and technological progress, to which we owe the great growth of new knowledge and technology. Pim Martens et al. [6] consider the objective assessment of the causes, contents and consequences of globalization as a key issue for contemporary research.

Factors that explain the origin and development of globalization are divided into 5 groups: [7] 
1. General factors and environmental factors (growing world competition, production and information technologies, development of the world economy, etc.).

2. Political and governmental factors (economic integration, liberalization of foreign trade, etc.)

3. Factors related to markets and demand (homogenization and internationalization of international demand, improvement of information and communication technologies).

4. Factors related to the subject of business, with strategic intentions and philosophy of the company.

5. Competitive and financial factors.

Five factors / phenomena accelerating the process of globalization:

1. Microelectronics - enabled the reduction of information transmission distance.

2. Presence of global problems of the planet - they cannot be solved at the level of individual states.

3. Reducing the ability of states to solve their own national problems.

4. Formation of powerful multinational companies.

5. Increasing the number of educated people. [8]

\subsection{Self-government}

Based on Art. 64a of the Constitution of the SR no. 460/1992 Coll., [9] - territorial selfgovernment represents the authority of regions and municipalities to make independent decisions, self-organize and self-account for a legally defined range of matters that are directly related to the interests of the population living in the territory. We divide selfgovernment into:

1. territorial self-government, which is divided into:

- local government - municipalities / cities,

$\circ$ regional self-government - higher territorial unit (VUC)

2. self-government of interest. (Characteristic features of self-government according to Hašanová [10]):

○ the existence of a community specific to its own needs and interests is taken into account by local authorities;

- a community to which the status of a legal person is conferred by constitution or by law. It is reflected in the principles of autonomy and independence.

- a community which elects its own bodies.

Territorial self-government represents the community of citizens, their interests and preferences, it is a representative of a pluralistic democratic system in a certain municipality or region.

\subsection{Regional marketing communication}

The task of marketing communication at the regional level is to inform about the activities and products of the city and to influence the target groups with its tools so that these activities lead towards a positive perception of the given locality, self-government, territory.

The essence of marketing communication of cities and municipalities can be summarized by the following attributes - building of the positive locality image, effective communication and its optimization, improving relations between citizens and employees, strengthening the identification of residents with the territory and creating suitable platforms for their participation in local development.[11] 
The self-government must communicate primarily in order to gain public support, inform the public, arouse public interest in the development of the territory, gain public understanding in solving problems, reach a mutual agreement between the various entities, promote its own territory in the market. [12]

\subsection{The Importance of innovation in self-government}

Among the changes that urge the introduction of innovations and underline their importance, we can include rapidly changing times, globalization, sustainability, uncertainty and many others. Inovative activities lead to the performance increase of a specific business entity. These activities are connected to the preparation and selling of an original idea. [2 ] Every entity operating in a business or social environment encounters these changes and must address them. Municipalities are no exception, namely the people / employees who work in it. Thanks to innovation, means and conditions are created in the self-governments, through which adaptation to change is easier and more natural. Theories of globalization tend to accentuation importance the role of regions in global economic restructuring. Globalization have reduced spatial barriers and asymmetry in development, and poor regions and rural areas may seize the new opportunities to develop their economies [13].

The emphasis on increasing efficiency in public administration is becoming more and more striking, as is the appeal for the openness of public administration towards citizens. Only an innovative public administration is able to respond and adapt to the changing conditions of public society.[14]

Author Rumpel [15] distinguishes 4 types of innovation in the public sector:

- institutional - organizational (e.g. the concept of New Public Management)

- innovation in financial management (e.g. public-private partnerships)

- product (e.g. science and technology parks)

- technical-technological (e.g. e-government)

The financial credibility of a local budget determines the competitiveness of a region and ensures the effective implementation of its economic objectives as well as the feasibility of the financial security of regional development. [16 ]

Based on the analysis and evaluation of the tasks and possibilities of the self-governments from the point of view of the application of institutional-organizational innovations, the authors of Žárska et al [17] formulated several recommendations, we chose the following:

- education as a platform for passing on and at the same time acquiring information, knowledge and insights must be a constant target of local governments. Lifelong learning, not only by self-government employees but also by marginalized groups, the unemployed, etc.

- increasing demands for the performance of functions in local self-government, implementation of methods of quality and efficiency of public services

- digitization of self-governments - creating conditions to be available online.

There are many opportunities for implementing innovations in the public sector. The majority of public services are being innovated to develop new solutions to a persistent problem, making services for citizens more efficient and effective. Innovation management should be in the hands of a team of managers, experts who are able to create the conditions for their implementation. These include finding opportunities, analysing resources and decision-making, an innovation plan, etc. Competitiveness is a driver of regional development, which depends on elements of territorial capital (a set of tangible and intangible, public and private resources), but also on territorial complexity (from territorial capital, but also from other factors as how regions innovate, what is the potential of urban growth and the structural dynamics of cities) $[18,19]$. 


\section{Methodology}

The pilot survey for the dissertation work was carried out in August 2019 and consisted of written questioning, in the form of a questionnaire, carried out at three local government authorities of the Trnava region - the City authority of Trnava, the Trnava self-governing region authority VÚC, and the Trnava district authority.

In the pilot survey, we decided to focus on an approach, in which the specific authority (or authorities) features as a sender of the message. The goal was to ascertain the level and system of utilising communication Instruments at an internal and external level. Furthermore, based on these results, we wanted to determine the main direction of the dissertation work's primary research.

The reason behind the survey on of internal and external communication use was the fact, that an internal communication system or instruments, managed by the institution and required for use by its employees, greatly influence the level and degree of effectivity, with which the given employees communicate with the public. This, in turn, influences the view of the particular institution in the eyes of the public.

We sent the questionnaires to the individual institutions and their departments in online form, via e-mail. Based on analysis of the hierarchical structure of the given institutions, we determined the number of the empty questionnaires in such a manner, that their number in every institution would be the same and would include every employee from the individual departments/sections of the authority.

As already mentioned, the respondents consisted of employees of individual authorities. The employees of local government authorities constitute a subgroup of subjects in regional marketing, which includes inhabitants, companies, organizations groups and associations, institutions, and similar, living and doing work within the given area. From this group, a subgroup - the employees of the authorities - differs from the group in that it itself is a part and to a certain extent also the creator of the marketing communication for the given area.

The questionnaire was divided into two parts, the first part of the questionnaire focused on ascertaining the method and system of internal communication at the individual authorities, and the second part having the goal of ascertaining the utilised communication instruments serving the external communication of the authority. We expected the number of filled-in questionnaires to be 99 . The actually received number of questionnaires was altogether 64 . We had received a reply in the form of at least one filled-in questionnaire, from every surveyed department, with the exception of the department of social affairs, which falls under the Trnava self-governing region. [20, 21, 22].

For the purposes of this article, we have chosen the following questions and their results. It's presented in the results chapter no. 3 .

\section{Results}

Do you perceive a systematic process in improving internal communication at your authority? 


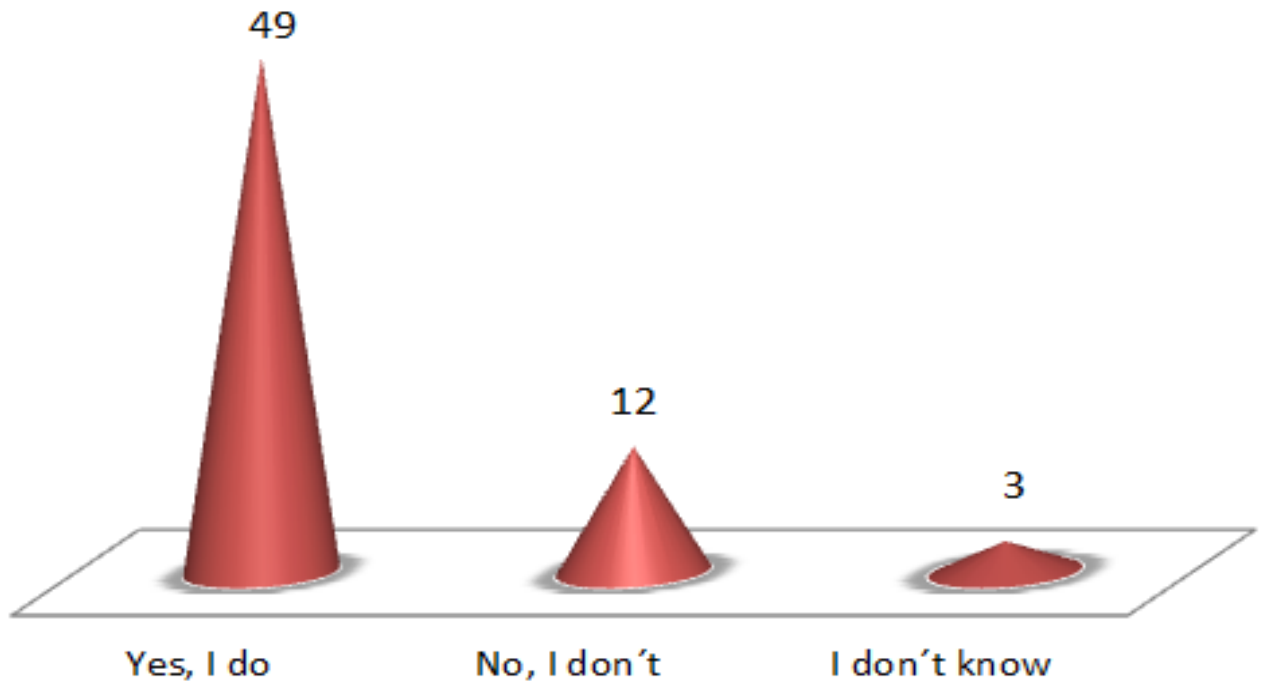

Fig.1. Improvement in internal communication.

49 respondents, $76 \%$ as a percentage, perceive an improvement in internal communication at their authority. The remaining respondents, 19\%, do not feel a movement towards improvement in the office and 5\% of respondents cannot assess it. The result of this question points to the inclination of the researched institutions to improve the system of internal communication in individual authorities.

Do you perceive it as necessary /important for your office to have the following communication channels (circle the options you perceive as necessary):
a) Facebook
b) Instragram
c) Web page
d) Application
e) I don't know
f) Other -

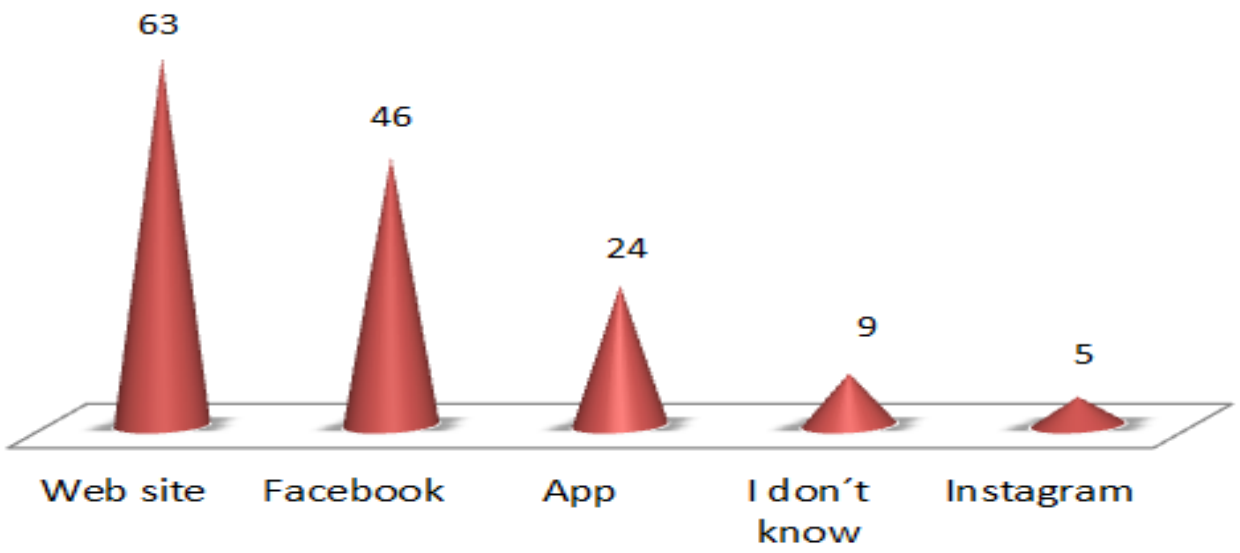

Fig. 2. Communication channels. 
Respondents could mark more than 1 answer in this question. The most marked answers were - Website, Facebook and Application. Instagram is on the last place. The question showed that even internal employees of the authorities, who are subgroup of the target group with which the local authorities communicate, are aware of the possibilities that arose after the arrival of the Internet in the field of communication between local governments and individual offices. A possible assumption from the results is that the respondents identified the options that use most often by themselves to obtain information.

Do you think that your office is willing to introduce innovations in external marketing communication?

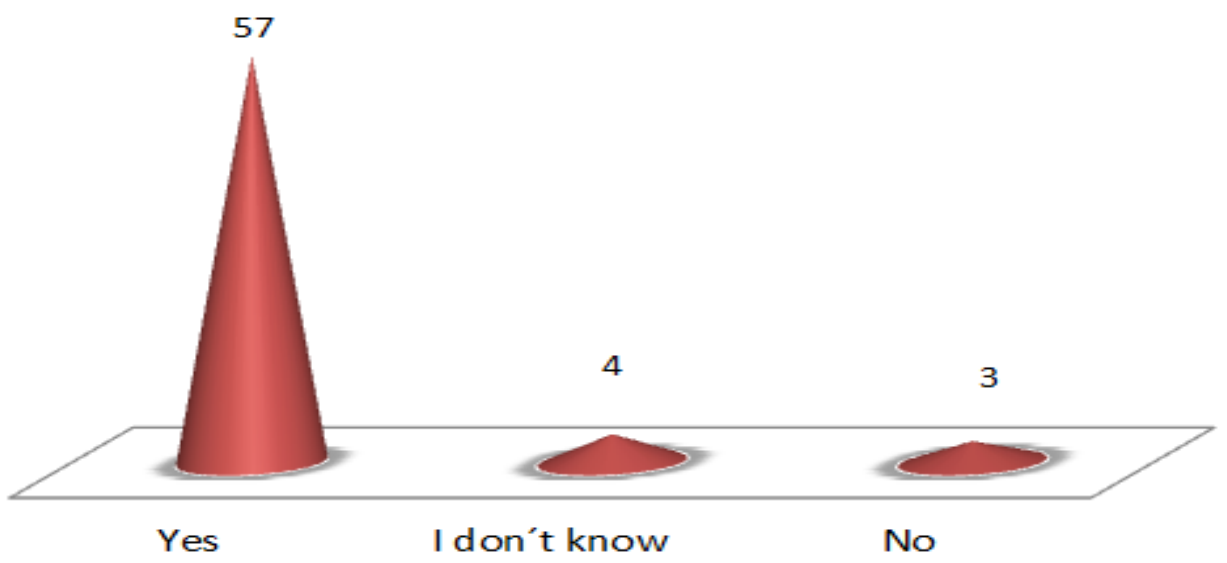

Fig. 3. Innovations in authorities.

The vast majority of respondents - 57 , which represents $89 \%$, think that their office is inclined to introduce innovations in external communication, 4 respondents could not assess this fact and the remaining 3 answered in the negative way. We considered it important to find out whether, from the point of view of the internal employees, local authorities tend to make progress and innovate in the way of external communication.

Do you think that the level and system of external communication of your authority has an impact on the overall image of the Trnava region? Mark the answer on a scale from 1 (not at all) to 5 (definitely yes).

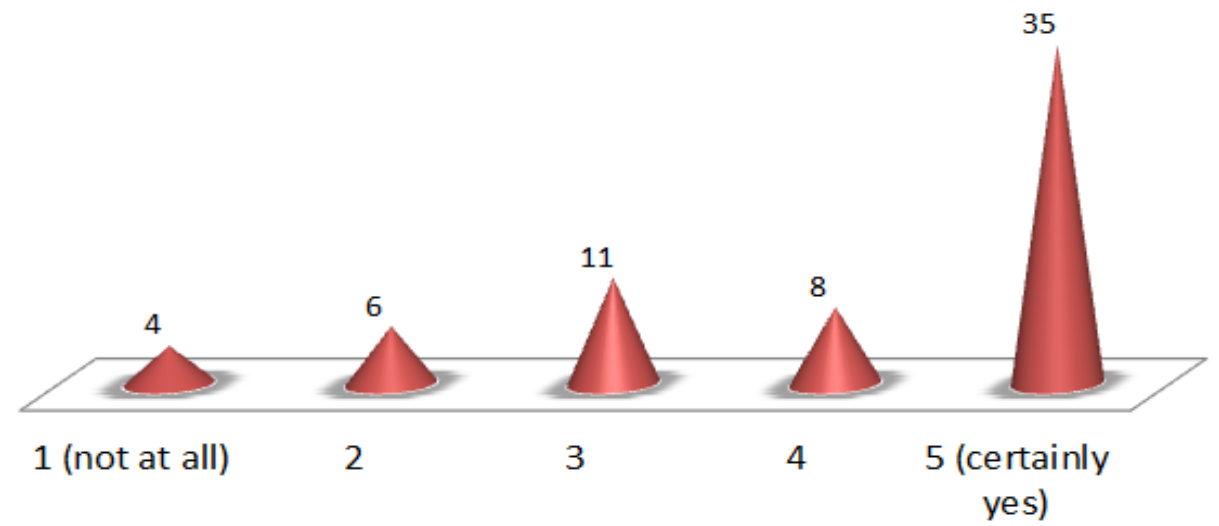

Fig. 4. Level of external communication. 
In the last question of the questionnaire, the respondents, on a scale from 1 to 5, expressed their opinion on whether the external communication of their office influences the overall image of the Trnava region. Most respondents, 35, 55\% marked the number 5 (certain yes), the number 3 marked eleven respondents and only 4 respondents think that external communication does not affect the image of the region at all. The average of the results of this question is at level 4.

\section{Discussion}

The internal employees of the three selected offices in the Trnava region differentiate the method of communication according to whom the message / information is addressed. Failure to receive feedback and an improperly chosen communication channel are the most frequently named obstacles that office workers encounter in the performance of their work. They also perceive the need for individual offices to have online communication channels in place. The most popular options were Facebook, Website and Application. Based on the results, the surveyed offices are inclined to introduce innovations and the level of external communication in the institutions influences the overall picture of the given area, as revealed by the survey.

\section{Conclusion}

Innovations and the issue of their implementation in the public sector is a very topical issue, primarily due to its insufficient definition. Local governments of cities and municipalities make an effort to introduce and implement innovations, but for them it is necessary to obtain financial support from the state and European Union funds.

The city of Trnava can be evaluated as a self-government that not only accepts innovations in marketing communication, but also tries to implement them, both within its external and internal operations. By choosing suitable marketing communication tools, it is possible not only to eliminate the consequences of negative impacts but primarily to strengthen the positive and strengths of the territory. By applying correctly set tools of marketing communication, it is possible to achieve set goals, visions and plans.

This paper is an output of the research project supported by the Grant Agency of the Ministry of Education of the Slovak Republic and the Slovak Academy of Sciences (VEGA) No. 1/0078/18 titled Aspects of Marketing Communication in the Management Processes of Circular Economy.

\section{References}

1. Beck U. (2004). What is globalization? Bratislava: Vydavatel'stvo Spolku slovenských spisovatel'ov.

2. Rybanský, J., Jánoš D. (2020). Globalization and its impact on healthy lifestyle. The $19^{\text {th }}$ International Scientific Conference Globalization and its Socio-Economic Consequences 2019 - Sustainability in the Global-Knowledge Economy (pp. 04022). Rajecké Teplice, Slovakia.

3. Krejči O. (2007). Medzinárodní politika. Praha: Vydavatel'stvo Ekopres.

4. Prilleltensky, I. (2012). The what, why, who, and how of globalization: What is psychology to do? Journal of Social Issues, 68 (3), 612-629.

5. Bartelson, J. (2000). Three concepts of globalization. International Sociology, 15(2), 180-196. 
6. Martens, P., Caselli, M., De Lombaerde, P. et al. (2014). New directions in globalization indices. Globalizations, 12(2), 217-228.

7. Chebeň, J. (2002). Globalizacia a rozhodovacie procesy podniku pri vstupe na medzinárodný trh. Nová Ekonomika, 5 (1), 53-61.

8. Rolný, I., Lacina, L. (2008). Globalizace, etika, ekonomika. Ostrava: Key Publishing.

9. Art. 64a of the Constitution of the SR no. 460/1992 Coll.

10. Hašanová, J., Dubor, L. (2019). Základy správneho práva. Prague: Aleš Čenek.

11. Dodecký, J. (2009). Inštitucionalizácia mestského marketingu na mestskom úrade a jeho realizácia. Recenzovaný príspevok z Medzinárodnej Batovej konferencie pre doktorandov a mladých vedeckých pracovníkov. Zlín: University of Tomáš Bat’a in Zlín.

12. Horváthová, M. (2012). Marketing miest a obcí. S dôrazom na marketingovú komunikáciu a vplyv informačno-komunikačných technológií na jej rozvoj. Košice: Metropola Trade.

13. Wei, Y. D., Lin, J., Zhang, L. (2019). E-Commerce, taobao villages and regional development in China. Geographical Review, 1-26.

14. Osborne, S. (2010). The New Public Governance. London: Routledge.

15. Rumpel, P. (2005). Vybrané aspekty rozvojových konceptú s dúrazem na teritoriální marketing. Zborník príspevkov z pracovného seminára. Ostrava: Ostrava university.

16. O. Liuta, N. Pihul, T. Kubakh. (2015). Financial capacity of local budget as a basis for sustainable functioning of a territory. Economic Annals, XXI, 1-2(1), 78-81.

17. Źárska et al. (2010). Vplyv inštitucionálno-organizačných inovácií na zvyšovanie znalostného potenciálu v miestnej samospráve. Nation Regional Economics, VIII, 7.

18. Cabello, R. (2019) Regional development theories and formalised economic approaches: An evolving relationship. Italian Economic Journal, 5(1), 1-16.

19. Bonancio, S., O'Reilly, J., O'Sullivan, S. L., et al. (2016). Nonverbal behavior and communication in the workplace: A reveiw and an agenda for research. Journal of Management, 42(5), 1044-1074.

20. Ferdere, J. P. (2008). Advances in commucation technology and growth of the American over-the-counter markets, 1876-1929. Journal of Economic History, 68(2), 501-534.

21. Belloc, M., Drago, F., Galbiati, R. (2016). Earthquakes, religion, and transition to sefgovernment in Italian cities. Quarterly Journal of Economics, 131(4), 1875-1926.

22. Crane, A., Glozer, S. (2016). Researching corporate social responsiblity communication: Themes, opportunities and challenges. Journal of Management Studies, 53(7), 1223-1252. 